\title{
The double-edged sword of antimalarials in cancer and COVID-19-infected patients
}

\author{
Antimalarika jako dvousečná zbraň u pacientů s rakovinou \\ a infekcí COVID-19
}

\author{
Mendoza L. \\ Hematology/Oncology Unit, IQVIA Inc., Prague, Czech Republic
}

The SARS-CoV-2 virus causes COVID-19, and it has reached pandemic levels since March 2020 exerting an unprecedented global impact on public health and health care delivery. The pandemic has impacted patients' access to cancer treatments, and in some cases, cancer treatment has been postponed, changed to an ambulatory treatment, or stopped. Several publications have indicated that patients with cancer appear to be at an increased risk of mortality and severe illness due to SARS-CoV-2 infection [1].

The antimalarial quinine analogue drugs, chloroquine (CQ) and the less toxic hydroxychloroquine (HCQ), which belong to the aminoquinoline class, were developed primarily to treat malaria. However, they are also indicated to treat patients with chronic discoid and systemic lupus erythematosus, and for acute and chronic rheumatoid arthritis in adults [2]. Due to their antiviral properties, the antimalarials have been used to treat patients with COVID-19. To date, there has been no conclusive data about the real benefit and safety of these drugs in COVID-19 patients [3]. Because highly efficient treatment alternatives are lacking, antimalarials are still used to control the viral infection in different parts of the world.

Autophagy is a catabolic mechanism of regulated intracellular turnover in which cells degrade cellular proteins, organelles, and cytoplasm that are engulfed, digested, and recycled to sustain cellular metabolism. It is associated with cell death and acts as tumour suppressor during cancer initiation. Autophagy also has a dual mechanism that enhances tumour cell survival by promoting metastasis through enhancing tumour cell survival. Several autophagy inhibitors, such as Lys05 family, ROC305 , GNS561, and those targeting lysosomes are being investigated and they are at different stages of clinical development [4]. Lysosomes are the intracellular organelles that play a critical role in the catabolic pathways that are driven by mTORC1 [5]. Antimalarial drugs, CQ, and $\mathrm{HCQ}$, inhibit lysosomal function; however, the mechanism of how to inhibit autophagy-lysosome function remains unclear [6]. Currently, CQ and HCQ are clinically available antimalarial drugs and several trials on autophagy inhibition have been conducted, but the clinical value of targeting autophagy therapy remains controversial. A recently published meta-analysis study that included seven clinical trials encompassing 239 cancer patients who were treated with either CQ or HCQ in combination with other anticancer treatments showed that autophagy-lysosome inhibitor-based therapy had a statistically significantly higher response rate, progression-free survival, and overall survival compared with the therapy without autophagy-lysosome inhibitors [7].

The COVID-19 pandemic is leading to new knowledge for physicians. We have recently become aware of the negative impact of antimalarials with or
The authors declare they have no potential conflicts of interest concerning drugs, products, or services used in the study.

Autoři deklarují, že $v$ souvislosti s predmětem studie nemají žádné komerční zájmy.

The Editorial Board declares that the manuscript met the ICMJE recommendation for biomedical papers.

Redakční rada potvrzuje, že rukopis práce splnil ICMJE kritéria pro publikace zasílané do biomedicínských časopisů.

$\equiv$

Luis Mendoza, MD, PhD

Hematology/Oncology Unit

IQVIA Inc.

Pernerova 691/42

18600 Prague

Czech Republic

e-mail: luis.mendoza@iqvia.com

Submitted/Obdrženo: 23. 10. 2020

Accepted/Přijato: 6. 5. 2021

doi: $10.48095 /$ ccko2021319

without macrolides in the treatment of cancer patients who are infected with COVID-19. At the American Society of Clinical Oncology (ASCO) virtual congress in 2020, a study was presented that included 1018 COVID-19-positive patients who were under active treatment or had previous hematologic or invasive solid malignancies reported at several academic and community sites. The multivariable regression analysis found several factors that were associated with an increased 30-day mortality rate, in- 
cluding HCQ and azithromycin treatment [8]. However, in a retrospective review of a study that was conducted in Spain, the authors reported that combined HCQ and azithromycin treatment showed a better outcome after a multivariate analysis, with only three deaths among 18 patients who received this treatment. It should be noted that this COVID-19 cancer patient analysis from Spain was small $(\mathrm{N}=45)$ [9].

Summarizing, we can say that autophagy-lysosome inhibition remains an attractive strategy to augment standard therapy and improve long-term outcomes for a broad range of malignancies. Despite previous studies having shown controversial results, the unique meta-analysis study indicated the benefit of these antimalarials. Many studies with CQ and HCQ are registered at clinicaltrial.gov, and they are further investigating the benefit of these drugs as autophagy-lysosome inhibitors in cancer. During the COVID-19 pandemic, a large number of cancer patients have been treated with CQ/HCQ-based ther- apy. The progress of anti-COVID-19 vaccination is dishearteningly slow, so the treatment of non-vaccinated people is still a burning issue. In above-mentioned recent data that were presented at the ASCO virtual congress, there was worrisome information about the use of HCQ-based therapy in all types of cancer patients, which was an independent factor that was associated with an increased 30-day mortality rate. This outcome and future data generated from studies with antimalarials as an anti-COVID-19 treatment or as an autophagy-lysosome inhibitor should be closely followed up to determine whether the negative consequences are reproduced in the autophagy-lysosome research or whether it is only related to COVID-19-positive cancer patients or both.

\section{References}

1. Saini KS, Tagliamento M, Lambertini M et al. Mortality in patients with cancer and coronavirus disease 2019: a systematic review and pooled analysis of 52 studies. European Journal of Cancer 2020; 139: 43-50. doi: 10.1016/j. ejca.2020.08.011
2. Plaquenil (hydroxychloroquine sulphate tables, USP). [online]. Available from: https://www.accessdata. fda.gov/drugsatfda_docs/label/2017/009768s037s045s047|bl.pdf.

3. Mendoza L. Chloroquine and hydroxychloroquine for the treatment of COVID-19 patients: what every clinician should know. [online]. Available from: https://papers.ssrn.com/sol3/papers.cfm?abstract_id $=3713$ 810.

4. Piffoux M, Eriau E, Cassier PA. Autophagy as a therapeutic target in pancreatic cancer. Br J Cancer 2021; 124(2): 333-344. doi: 10.1038/s41416-020-01039-5.

5. Towers CG, Thorburn A. Targeting the lysosome for cancer therapy. Cancer Discov 2017; 7(11): 1218-1220. doi:10.1158/2159-8290

6. Rebecca WW, Nicastri MC, McLaughlin N et al. A unified approach to targeting the lysosome's degradative and growth signaling roles. Cancer Discov 2017; 7(11): 12661283. doi:10.1158/2159-8290

7. Xu R, Ji Z, Xu C et al. The clinical value of using chloroquine or hydroxychloroquine as autophagy inhibitors in the treatment of cancers: a systematic review and meta-analysis. Medicine (Baltimore) 2018; 97(46): e12912. doi: 10.1097/MD.0000000000012912.

8. Warner JL, Rubinstein S, Grivas P et al. Clinical impact of COVID-19 on patients with cancer: data from the COVID19 and Cancer Consortium (CCC19). [online]. Available from: https://ascopubs.org/doi/10.1200/JCO.2020.38.18_ suppl.LBA110.

9. Rogado J, Obispo B, Pangua C et al. Covid-19 transmission, outcome and associated risk factors in cancer patients at the first month of the pandemic in a Spanish hospital in Madrid. [online]. Available from: https://link.springer.com/article/10.1007/s12094-020-02 381-z. 